Леонід Чекаль

\title{
ПРОБЛЕМИ ФІЛОСОФІї ТА МЕТОДОЛОГІї ТЕХНІКИ
}

XX століття продемонструвало біфуркаційність історичного процесу, виявило наростаючі кризові тенденції в європейській цивілізації. В їх основі - невпинно інтенсивний розвиток науки i техніки. Філософія техніки як рефлексія над технікою покликана зафіксувати тенденції розвитку технічного і технологічного знання специфічної сфери духовної діяльності в їх історичному розвитку та соціокультурному контексті. Аналіз філософських концепцій техніки дає можливість збагатити існуючі філософські парадигми, з одного боку, з іншого - представити філософію техніки як гуманізований вимір техніки, як прагнення людини сотворити і пізнати себе з позицій самих високих критеріїв.

Техніка та технологія в історії людства існували завжди, оскільки сама ця історія починається не раніше того, як люди починають використовувати штучні знаряддя ручної праці, тобто найпростішу техніку. Грецьке слово "техне" в перекладі українською мовою означає мистецтво, майстерність, вміння. Воно зустрічається вже у Платона та Арістотеля у зв'язку з аналізом штучних знарядь праці. Вихідним моментом техніки є природні продуктивні органи людини, передусім руки. Доповнення, підсилення, заміщення природних робочих органів людини мають певну соціальну детермінацію, яка реалізується шляхом використання природи та втілення в природних тілах трудових функцій.

Створений людиною об'єкт називають артефактом (латиною "артефактум" - "штучно зроблений"). Техніку можна вважати сукупністю артефактів, але таке визначення техніки, зрозуміло, дає лише перше уявлення про неї.

Історичний шлях людини нерозривно пов'язаний з ускладненням та постійним розвитком техніки. Остання пройшла дуже довгий шлях, перш ніж сягнула нинішніх висот. У доіндустріальному суспільстві техніка була ремеслом, що засно- 
вувалось на процесах диференціації та спеціалізації робочих знарядь. Технічне вміння передається від майстра до учня в межах ремісничо-цехової організації праці. Такі вміння та знання залишалися здобутком замкненого кола осіб і не одержували відповідної суспільної оцінки.

Проте людська історія здебільшого визначається розвитком техніки і певною сукупністю підвладних для даного суспільства технологій. Необхідність підвищення продуктивності праці зумовила функціональне членування знарядь праці. Кожний новий інструмент призначався для виконання однієї або кількох виробничих операцій і кількість цих операцій зменшувалась порівняно із застосуванням попереднього інструмента. Однак аж до Промислової революції техніка і технологія не мали того загальноуніверсального й детермінуючого характеру, якого вони набувають уже в Новий час, а особливо - у новітні часи.

Цивілізації, які змінювали одна одну до Нового часу, були вельми неоднаковими за своїми базовими характеристиками. Вони могли сповідувати різні релігії, їхні цінності та мотивації, могли бути діаметрально протилежними, але всі вони використовували в повсякденному житті той самий перелік технічних засобів, що є комбінацією механізмів, які були відомі ще в прадавні часи. Колесо, клин, важіль, блок, гвинт - і є та основа технічного арсеналу, яка притаманна всім відомим історії людським суспільствам. Проте своєрідність тієї чи іншої цивілізації визначалась зовсім не рівнем технічного розвитку. Ї̈̈ потужність та авторитет не залежали від останнього. У свою чергу технічний прогрес не був ані метою, ані навіть переважаючою домінантою розвитку більшості відомих в історії цивілізацій. Ситуація починає швидко змінюватись саме в Новий та новітній час, коли техніка Західної цивілізації, що все ще була комбінацією тих самих найпростіших механізмів давнини, стала приводитися в рух енергією пари, мінерального палива, електрики i, нарешті, атомного розпаду. Потужність нової техніки була такою великою, що жодна держава світу не могла дозволити собі ігнорувати те, що відбувалося у сфері техніки. Суспільство могло або загинути - що сталося з автохтонними цивілізаціями Америки, або підкорятися загальному процесу та застосувати в себе ті 
елементи культури Заходу, якими визначалась ii потужність. Тільки так техніка стає високоуніверсальним феноменом сучасної історії людства.

Важливо підкреслити таке: немає людини та суспільства поза техносферою, техніка історична, вона не стоїть на місці, оновлюється. Технічні інновації стають каталізатором, бродилом, імпульсом докорінних змін у всій системі людського життя.

Вивченню феномену техніки приділяється належна увага лише останні 100 років. Перші фундаментальні роботи з філософії техніки з'явились наприкінці XIX ст. У 60-70-х роках нашого сторіччя філософія техніки розвивається досить інтенсивно і стає самостійним напрямом філософського знання.

Філософія техніки - одна 3 наймолодших гілок філософського знання. Філософія, переймаючись найбільш загальними, фундаментальними проблемами, тривалий час не потребувала вивчення проблем техніки. При цьому вона не тільки вважала, що ці проблеми не варті уваги, але й розглядала техніку як таку, що не $є$ складовою предметного поля філософії. Однак, не будемо відкидати того факту, що деякі з філософів (Арістотель, Альберт Великий та ін.) приділяли увагу й техніці - як природознавці та винахідники. При цьому соціальні проблеми, які породжувались технікою, 3 давніх давен ставали предметом філософської рефлексії (приклад - "Даодецзіню", в якому вже у VI ст. до н. е. засуджувалось використання нових знарядь праці, тобто технічний прогрес), але тут досліджувалось саме суспільство, а не техніка як самостійний феномен. I тільки з усвідомленням того, що техніка в сучасному суспільстві $є$ однією із загальних детермінант, виникає справжня зацікавленість у філософському дослідженні власне техніки.

Перші праці, що були присвячені філософському розумінню проблеми техніки, вийшли у світ більш як сто років тому. Приміром, у 1877 р. у Брауншвейзі було видано книгу філософаантрополога Е.Каппа "Засади філософії техніки", яку й прийнято вважати початковою сходинкою у систематичній філософській розробці проблем техніки. Приблизно в той же час у Франції А.Еспінас працював над побудовою загальної теорії техніки, яка спиралась на філософські засади й категорії. Завершено цю ро- 
боту було у 1897 р. Щодо російських філософів, то треба згадати праці відомого інженера П.К.Енгельмейєра ("Теорія творчості", 1910 р. та "Філософія техніки", 1913 р.). На межі століть виходять 3 друку також праці англійських філософів, які розробляли технічну проблематику. Але все це були окремі, розрізнені дослідження.

Загалом же до другої світової війни внесок сучасної техніки у цивілізацію лише оптимістично схвалювався, а безперервний технічний прогрес здавався чимось навіки даним та стверджуючим ідею панування людини над природою. Справжня зацікавленість у філософському тлумаченні проблем техніки виникає пізніше і починається із всесвітніх філософських конгресів 1968 р. у Відні, 1973 р. у Варні та 1978 р. у Дюссельдорфі. 3 того часу кількість друкованих праць, присвячених цій проблематиці, починає стрімко зростати, хоча й пізніше знаходились філософи, які висловлювали сумніви щодо філософських проблем техніки.

Ці підходи живились ще й такими обставинами. По-перше, західна філософська традиція звикла розглядати техніку як ремесло, а в кращому випадку - як практичне застосування накопичених знань. 3 технікою пов'язувалась діяльність, яка $\epsilon$ обмеженою щодо інтелектуального змісту, яка не варта філософського дослідження. Філософія ж розглядалась як частина царства духу, який протистоїть практичній діяльності, заснованій на інтуїтивному вмінні робити щось.

По-друге, тенденція розглядати людину виключно як "animal rationalis" стверджувалась завдяки тому, що марксистська традиція, яку не сприймали на Заході, приділяла техніці як частині так званих продуктивних сил суспільства підвищену увагу, підкреслюючи, що саме рівнем їхнього розвитку й визначається рівень суспільного, культурного й морального прогресу людства. Таке розуміння детермінант історичного процесу не могло не зустріти протидію на Заході, наслідком чого і було нехтування філософським аналізом техніки.

Тільки з усвідомленням суперечності між традиційною ідеєю нескінченного прогресу та близькістю "меж зростання", характерної для 1960-х років, філософія техніки виразно стверджується як окрема гілка філософського знання і одразу ж на- 
штовхується на неминучі труднощі, що внутрішньо притаманні предмету дослідження.

Нині не існує чіткого та однозначного визначення поняття "техніка", хоча нібито всі інтуїтивно розуміють, що таке "техніка". Однак будь-яка спроба дати однозначне коректне визначення зазнає невдачі.

Якщо під технікою розуміти штучно створені речі (артефакти), то виникає питання: а як тоді бути, приміром, 3 міськими забудовами? А щодо картин та скульптур? А як бути 3 промисловими відходами? Як бути з породами свійських тварин та рослин, які також певною мірою створювались штучно? Окрім того, ми говоримо про "техніку пілотування" у льотчиків, про "техніку гри" у музик, про "техніку читання" у школярів. А наше універсальне визначення техніки 3 необхідністю повинне охопити всі ці сутності.

Можна спробувати виділити найсуттєвіші ознаки техніки й побудувати філософське визначення на їхній основі. Німецькі філософи техніки X. Ленк та Г. Рополь здійснили аналіз прикмет техніки, виявлених у німецькій філософській літературі, їх нараховується теж більш як десяток - від "прикладного природознавства" до "волі до влади та підкорення природи", при цьому простий перелік ані на крок не наближає нас до розуміння природи досліджуваного феномену та розробки його цілісного й несуперечливого визначення. Стан речей ускладнюється ще й у зв'язку з розбіжностями у тлумаченні слів "техніка" та "технологія". Ще П.К.Енгельмейєр вдався до використання в російській філософії терміну "філософія техніки", яким ми користуємось й нині. Водночас у англомовній (найдоступнішій та наймасовішій) літературі цей термін виглядає як "philosophy of technology", але це зовсім не є "philosophy of technique". Отже, згадуючи про філософію техніки у західному іiі розумінні, ми змушені розуміти швидше "філософію нерозподільних технікитехнології". В іншому випадку більшість контекстів західних авторів ризикують залишитись для нас незрозумілими або зрозумілими неадекватно. Так, наприклад, французький філософ Ж.Еллюль визначив техніку як "суму раціонально напрацьованих методів, яким притаманна безумовна ефективність ... у 
будь-якій сфері людської діяльності". Як бачимо, і тут мова йде про "техніку і технологію". Німецький філософ Ф.Раппе, аналізуючи існуючі у філософській літературі визначення поняття "техніка", також намагався створити універсальне визначення "техніки-і-технології". На його думку, можна виділити два типи визначень - вузьке й широке.

Щодо вузького визначення - то тут техніку тлумачать як сукупність предметних артефактів, створених для здійснення інженерної перетворюючо-конструктивної діяльності. Таких визначень багато. Але всі вони мають у собі головне: в них варіюється та фундаментальна якість техніки, яку можна було б назвати принципом перетворення. Тобто техніка $є$ тим, за допомогою чого людина перетворює природу, саму себе, суспільство. I основною соціальною функцією, культурним покликанням техніки є конструювання та реконструювання предметної реальності. Техніка репрезентується за допомогою знарядь, предметів або алгоритмічно-технологічно. Техніка $є$ тим, чим людина справляє вплив на об'єкти, змінюючи їх. Але техніка є і тим, як саме вона діє щодо цих об'єктів, це теж техніка, яка вже тут виявляє себе як технологія.

Сучасна філософія техніки в цілому не є завершеною, більше того, вона досі навіть не являє собою певної філософської цілісності. Переважно це зумовлено "дитячим" віком цієї філософії, відсутністю дослідницьких традицій, систематичності в накопиченому знанні, а також єдності у використовуваній термінології.

Свого часу за вирішення різноманітних проблем філософії техніки бралися такі видатні філософи XX ст., як М.Хайдеггер, Г.Маркузе, Е.Дюркгейм, А.Бергсон, К.Ясперс. Проте навіть їм не вдалося створити несуперечливі, цілісні й систематизовані рішення. Більше того, своєрідна, свідомо ускладнена мова творів М.Хайдеггера, приміром, зумовлювала незрозумілість цих робіт для більшості практичних інженерів. А К.Ясперс, що критикував у своїх працях антропологічні наслідки технічного прогресу для індивіда та суспільства, не дуже заглиблювався у предмет своєї критики. Отже, нагально постала проблема необ- 
хідності специфічної міждисциплінарної підготовки дослідників щодо філософії техніки.

До їх числа можна віднести, окрім суто філософських суперечок про онтологічний та гносеологічний характер сучасної техніки, такі проблеми, як: наслідки застосування комп'ютерів і, зокрема, можливість створення штучного інтелекту; зростаюча складність сучасної техніки та пов'язана із цим необхідність іiі оцінки; взаємозв'язки між технікою та суспільством, наукою та природою, шляхи й перспективи подальшого розвитку техніки тощо.

Проблема наслідків комп'ютеризації суспільства та створення штучного інтелекту є однією з головних у сучасній літературі 3 філософії техніки. Можна виділити певні напрями у цій сфері. Передусім, це праці, присвячені соціальним наслідкам комп'ютеризації. На Заході змалюванню даного феномену були присвячені сотні томів. Тут звертається увага на те, що із застосуванням сучасних комп'ютерних засобів докорінно змінилися практично всі сфери життя сучасного суспільства - від державного управління до освіти й культури. Широко обговорюються й проблеми, зумовлені цими змінами, - такі як перетворення інформації на свого роду глобальний ресурс людства, потенційно можливе зростання відчуження людини в інформаційному суспільстві, зміни у соціальному грунті такого суспільства. Філософи цього напряму намагаються сягнути соціопрогностичного рівня, не тільки змальовуючи суспільство, але й прогнозуючи його соціальний розвиток. Класичним прикладом цього напряму може бути Г.Маклюен та його концепція "глобального села".

Певною мірою осторонь цих праць стоять роботи, присвячені проблемі створення штучного інтелекту, яка безпосередньо пов'язана 3 головними шарами філософської проблематики. Можливості сучасних технічних систем в обчисленні, розпізнаванні образів, перекладі, цілеспрямованій поведінці настільки значущі, що потребують перегляду традиційної межі між людським "духом" та машиною.

Реакція філософів щодо цієї проблеми складається з констатації того факту, що навіть за умов найточнішого моделювання сутнісні риси людини зникають при спробах їх відтворення в 
комп'ютерній програмі. Але традиційним уже $є$ й контраргумент про невичерпні можливості розвитку апаратних засобів i програмного забезпечення, які дуже скоро зроблять таке відтворення можливим.

Сучасні програмні засоби спроможні не тільки навчатись та самонавчатись, а й здатні до так званої інтерактивної поведінки й корекції помилок, до самостійного пошуку та отримання інформації. Така поведінка може розглядатися як свідома, що саме по собі викликає певні труднощі. Ще більші труднощі може викликати філософська інтерпретація поведінки інших програм комп'ютерних вірусів, здатних до свавільного копіювання, тобто розмноження, а також до зовсім інших дій, незалежних від волі людини, а іноді - й всупереч їй.

Чи означає це, що людина створює певне нове життя, свого роду "духу в людині"? Захисником цієї точки зору є прихильник біхевіористської інформаційної теорії пізнання К.Сейр. У своїй роботі "Кібернетика та філософія розуму" він одстоює думку, згідно з якою комп'ютер чи комп'ютерна програма здатні до дій та цілеспрямованої поведінки, типової для людини. Отже, такі продукти можуть мати свідомість, що, зрештою, призводить до заперечення якісних розбіжностей між природою фізичних та духовних явищ.

Протилежний погляд означає, що машина чи програма створюються людиною i, в цьому сенсі, є відображенням тієї мети, яка була попередньо висунута людиною і для реалізації якої ця програма повинна виконуватись. У цьому випадку здатність програми до цілеспрямованої поведінки визначається її творцем.

Врешті-решт, питання про можливості створення штучного інтелекту, який був би рівним або й навіть переважав людський розум, зводиться до традиційного філософського питання про природу людського розуму взагалі. Без вирішення останнього навряд чи можливим $є$ створення штучного інтелекту. Відомий польський письменник-фантаст і філософ С.Лем запропонував незвичайне вирішення цієї дилеми. Він припустив, що магістральним шляхом розвитку для комп'ютерів буде моделювання не інтелекту, а інстинктів та тропізмів. На його думку, розвиток штучного інтелекту суперечить одній з головних домінант усьо- 
го технічного прогресу - принципу доцільності. I, оскільки більшість цілей, які постали перед розробниками сучасних інформаційних систем, можуть бути досягнуті поза звертанням до принципу штучного інтелекту, остільки створення самого штучного інтелекту стає другорядним завданням.

Отже, сама постановка проблеми про наслідки створення штучного інтелекту $\epsilon$ не досить коректною. Але в будь-якому випадку відповідь на питання про те, чи здатні машини до самостійного мислення, буде ще довго бентежити думку філософів.

Ця проблема, народжена потребами адекватного управління довгостроковими інвестиціями у складні та великозатратні технічні проекти, є надзвичайно гострою та актуальною. Йдеться про те, що ще перед реалізацією такого проекту ми з необхідністю повинні усвідомлювати всі наслідки запланованої інновації. До чого призведе запровадження нової техніки? Як воно відіб'ється на економічній ситуації, на політичних обставинах? А щодо довкілля та здоров'я людей? А щодо відтворення населення? Безпеки країни?.. Відповідь слід мати ще до створення нової техніки, бо виправлення помилок на стадії проектування може коштувати набагато більше, ніж початкова вартість самого проекту.

Оцінка техніки й була призначена враховувати соціальнозначимі наслідки другого й третього порядку для масштабних технічних проектів. Але традиційні інженерні методи й критерії тут неспроможні. Техніка сама по собі ціннісне нейтральна і не може бути ані поганою, ані гарною. Наприклад, чим $\epsilon$ "сам по собі" автомобіль: чи предметом гордості й престижу, який забезпечує людині вільне пересування, чи чотириколісним монстром, який вбиває людей та отруює атмосферу? Відповідь на таке питання не може бути забезпечена жодним з методів, жодною 3 інженерних дисциплін. Більше того, таку відповідь не можна отримати апріорно й раціонально, бо вона цілком залежить від того переліку базових цінностей, на яких ми грунтуємось, намагаючись відповісти на зазначене питання.

Отже, якості й характеристики, які людська свідомість пов'язує 3 технічним об'єктом, виявляються більш залежними від самої свідомості, ніж від особливостей об'єкта. I таким чи- 
ном, вторинні наслідки технічної інновації визначаються не стільки якостями самого проекту, скільки ціннісними характеристиками. При цьому питання про ціннісну навантаженість "запланованої інновації" стає надзвичайно важливим.

Для робіт 3 оцінки техніки необхідним $є$ не просто соціологічне чи методологічне, а - філософське підгрунтя. I на цьому філософському - рівні проблема розроблялась американськими філософами В.Байєром, К.Парселом, Г.Портером, Г.Решером та ін., які розглядали проблеми аксіології техніки, методів іiї оцінки, вдосконалення планування технічних інновацій тощо. Ці вчені зазначали, що досконале, достовірне, теоретично обгрунтоване планування технічного прогресу було б рівнозначним спробі стилізації історичного процесу за певним заданим зразком. Окрім того, така спроба пов'язана 3 певними хибами, неприпустимими для демократичного суспільства.

А оскільки неможливо передбачити зміни ціннісних орієнтацій майбутніх поколінь, то неможливим $€$ й гарантування того, що навіть найкраще рішення, прийняте сьогодні, залишиться добрим і для наших нащадків.

Однією з класичних філософських проблем, яку висуває філософія техніки, $є$ питання про походження техніки та її взаємозв'язок з природою та суспільством. На філософському рівні це питання означає спробу дослідження процесу формування нової техніки, тобто процесу науково-дослідних та конструкторських робіт. Він, цей процес, є аналогічним процесові дослідження в науці, а, отже, може бути дослідженим за допомогою гносеологічних методів. Проте, оскільки техніку не можна звести до прикладного природознавства, остільки існує принципова розбіжність між створенням нової техніки та процесом наукового пошуку. Так, автори нової наукової теорії мають на меті розкриття якнайзагальнішої закономірності. Щодо творців нової техніки, то зазначеним вони майже не переймаються: їх мета - розробка конкретного технічного рішення. I тому, на відміну від природознавства, техніка формується як знання "для даного випадку", що тягне за собою істотні розбіжності у гностичних методах техніки й науки. 
Природознавство, прагнучи сягнути об'єктивної, незалежної від волі самого природознавця, картини світу, намагається мінімалізувати ті неминучі викривлення, які додає до світобудови

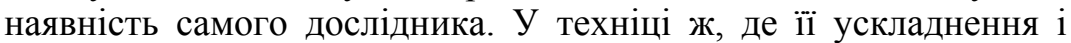
вдосконалення є головним гностичним актом, ситуація протилежна: об'єкт дослідження постійно змінюється в ході пізнання як залежно від самого цього ходу, так і від волі своїх творців. Наприклад, створюючи нову модель літака, iї досліджують в аеродинамічній трубі, i, залежно від результатів випробування, конструкція може підлягати певним змінам. Але останні можуть бути здійснені щодо цієї конструкції не тільки на основі цих іспитів, - вони можуть мати й довільний характер.

$€$ й інша точка зору, яка не визнає таких глибоких розбіжностей між природознавством та технікою. Зокрема, серед марксистських дослідників популярним є підхід, який передбачає не роз'єднання науки й техніки як окремих феноменів, а розгляд єдиного феномену сучасної науки й техніки. Така точка зору адекватна відомій марксистській тезі "про перетворення науки на безпосередню продуктивну силу суспільства". $€$ й дещо парадоксальний підхід німецького філософа П.Яніха, який у своїй роботі "Фізика - природнича наука чи техніка?" стверджує, що діяльність фізики, яка грунтується на спогляданні, вимірюванні та експерименті - $\epsilon$ технічною діяльністю, а сама фізика, певним чином, є різновидом техніки, яка відбиває поведінку тих чи інших артефактів. На думку Яніха, фізика як наука грунтується на застосуванні приладів, які по суті своїй є технічними артефактами. Більше того, з точки зору фізики, науковий результат стає таким саме тоді, коли ми від простого споглядання об'єктивних сутностей можемо перейти до їхнього вимірювання. Але при цьому будь-яке вимірювання $\epsilon$ засобом для виробництва штучних, тобто технічних, явищ. А фізичний експеримент Яніх змальовує як специфічним чином організований штучний об'єкт, оскільки для його постановки ми завжди повинні технічно реалізувати ті чи інші умови експерименту. Підсумовуючи зазначене, Яніх твердить, що швидше природознавство слід вважати вторинним наслідком техніки, ніж техніку - застосуванням природничих наук. 
В наш час ключовим постає питання про взаємозв'язок техніки з природою та суспільством. Традиційні уявлення про парадигми технічного прогресу як безмежного шляху "покращення" були засновані на двох головних ідеях науки та філософії Нового часу. Перша 3 них - це теза про безмежність природних ресурсів планети, а друга - про людину як "царя природи", який покликаний панувати над нею. Обидві ці засади є хибними. Ресурси планети обмежені, і ці межі очевидні вже зараз. А отже, необмежене екстенсивне зростання $є$ неможливим. Окрім того, дедалі більшої популярності нині набуває розуміння місця людини в природі, яке грунтується на визнанні того, що людина тільки частка природи і не може існувати поза нею. Цим пояснюється необхідність філософського усвідомлення феномену технічного прогресу, тобто зв'язків між технікою, природою та людиною.

Яким шляхом піде в майбутньому розвиток технічної цивілізації? Та й взагалі, чи має вона це майбуття, чи розпадеться, не витримавши власної ваги та винищивши біосферу планети? Як пов'язані між собою технічний та суспільний прогрес? I якщо, наприклад, технічний прогрес уповільниться або й зупиниться, то яким чином це відіб'ється на соціальному полотні, чи не призведе це до стагнації та регресу? Іншими словами, постає головне для даної проблематики питання: що є визначальним для розвитку у парі "суспільство-техніка" і що є детермінантою прогресу?

Однозначної відповіді на всі зазначені питання не існує. Маємо лише обирати між різними точками зору у філософії техніки. Йдеться, передусім, про моделі детермінізму в соціальному та технологічному розвитку людського суспільства. Якщо розподілити їх на дві великі групи, то разом з Ф.Раппом назвемо їх моделями "технологічного" і моделями "ціннісного" детермінізму.

Різноманітні форми технологічного детермінізму мають значну популярність передусім у марксистському осередку. К.Маркс започаткував таке розуміння історичної ходи, де визначальним є рівень розвитку продуктивних сил (стан техніки даного суспільства), який визначає рівень виробничих відносин 
(вся соціальна картина цього суспільства). Далі вводиться поняття "спосіб виробництва", який визначає "формацію". Як тих, так і інших тут нараховується п'ять - первісна, рабовласницька, феодальна, капіталістична та, у перспективі, соціалістична й комуністична як вінець усієї історії. Специфічним тут є розуміння технічного процесу як незалежного не тільки від індивіда, але й від суспільства в цілому. Саме ходою цього процесу визначаються всі соціокультурні зміни, які відбуваються в суспільстві. Дії людей тут розглядаються як цілком вільні, а не спонтанні. Вони обмежені тим переліком засобів, який пропонує їм існуюча в даному суспільстві технологія. I, напевно, в цьому прихильники технологічного детермінізму мають рацію. До них Ф.Рапп зараховує таких відомих філософів, як Ж.Еллюль, Г.М.Маклюен, А.Хабермас, Г.Маркузе та Т.Адорно.

Щодо прихильників іншого напряму - моделі "ціннісного" детермінізму, то вони слушно зазначають, що розвиток техніки не є процес, який підкоряється необхідності законів фізичного світу. Техніка розвивається на грунті свідомої діяльності людей i саме завдяки цій діяльності. Діяльність же людини детермінується аксіологічно. Отже, розвиток техніки визначається вільним вибором цінностей стосовно світу технічної дії. Цей вибір можна тлумачити як граничний моральний акт, що не зводиться до зовнішніх обставин.

Істотними труднощами для даної моделі технологічного розвитку є те, що магістральні напрями розвитку сучасної техніки виявляються незалежними від соціальних, політичних систем, а також від пануючих у суспільстві релігій з їхніми розвинутими ціннісними системами. Отже, модель ціннісного детермінізму має таке ж обмежене застосування, як і модель технологічного детермінізму.

Поряд 3 проблемою розуміння визначників технічного та історичного прогресу ще нагальнішою постає необхідність виробки ідеалів нашого подальшого розвитку. Ця проблема побудови адекватних моделей розвитку є нормативною і підносить філософію техніки на соціопрогностичний рівень. I хоча точне планування технічного прогресу є рівнозначним спробам моде- 
лювання прогресу історичного, однак потреба у виробленні нових ідеалів є вельми актуальною.

Існує декілька груп різноманітних нормативних моделей розвитку техніки. Одна 3 них є традиційною, або "моделлю $H T P "$. Грунтується вона на принципах технологічного детермінізму. Ця модель має популярність як на Заході, так і на вітчизняних теренах. Вона досить оптимістична і виходить з необмежених сподівань щодо можливостей людського розуму. Технологічний прогрес у межах даної моделі сприймається як найвище благо та основа всіх позитивних соціальних змін. Тут зазначається, що швидкість технічного прогресу останнім часом підвищується у зв'язку із зростанням науки (це і $є$ НTP) і що такий стан збережеться і в майбутньому.

Альтернативні думки, пов'язані з обмеженістю природних ресурсів і можливостей адаптації довкілля, в межах даної моделі, звичайно, відкидаються. Першим аргументом тут $\epsilon$ твердження, що людський розум, безперечно, буде спроможним в історичній перспективі підшукати замінники всім невідновлюваним ресурсам. Другий аргумент, що відкидає тезу про обмежену здатність природи впоратись із зростаючим техногенним тиском, грунтується як на вірі в потужність розуму наших нащадків, так і на тому висновку, що людство ще 3 часів виникнення осідлого землеробства живе практично не в умовах дикого природного середовища, а в умовах організованих, технологізованих ландшафтів (найпростіший приклад - засіяне житом поле). Отже, техніка, що звернена на організацію дикої природи, зможе перетворити іiї на цілком адекватне середовище для існування людини.

Тобто логіка тут очевидна: нехай зникнуть річки - ми створимо штучні озера; або: нехай гинуть ліси - ми насадимо садків..

Однією з домінуючих і найбільш впливових на Заході моделей є "загальна модель". Вона грунтується на міркуванні про розумність, корисність, безпечність можливих технічних проектів. Ця модель зумовлена нагальною проблемою сучасної техніки, яка пов'язана 3 нашою активністю щодо реалізації масштабних і довгострокових технічних проектів та водночас - нашим 
незнанням щодо тих наслідків, до яких призведе ця реалізація. В межах даної моделі головна увага приділяється розробці методів оцінки техніки, про які зазначалось вище. 3 точки зору прихильників даної моделі, технічний прогрес $є$ неминучим, проте менеджер, який приймає рішення про технічну інновацію, повинен бути попередженим і компетентним.

I, нарешті, "модель обмеження" узагальнює підходи, які грунтуються на необхідності обмеження або людських потреб, або масштабів технічних проектів. Тут досліджуються ті критичні межі, за якими вдосконалення техніки робить більше шкоди, ніж користі. Моделі обмеження людських потреб звичайно пропонуються для застосування у країнах, що розвиваються, враховуючи обмеженість їхнього достатку та високі темпи зростання населення. Моделі другого типу припускають, що оскільки ті ж самі людські потреби можна задовольнити за допомогою техніки найрізноманітніших видів, то потрібно уважно дослідити їх та застосувати ті з них, від яких найменше шкоди. Сучасні "зелені" максималізували саме цю модель розвитку техніки. Виходячи 3 економічних міркувань, вони вважають, що людство повинне відмовитись від переваг у ставленні до природи та жити простим життям пращурів. 